Слабкий Г.О., Миронюк І.С., Брич В.В., Білак-Лук’янчук В.Й.,

Маркович В.П., Потокій Н.Й., Яцина А.Т., Фейса I.І., Гуцол І.Я.

\title{
Освітньо-наукова програма підготовки магістрів громадського здоров'я Ужгородського національного університету очима стейкхолдерів
}

\author{
ДВНЗ «Ужгородський національний університет», м. Ужгород, Україна
}

g.slabkiy@ukr.net, ivan.mironyuk@gmail.com, leravvv79@gmail.com, bilak.vika@gmail.com,

v.markovych@i.ua, rigerbird@gmail.com, andreayatsyna@ukr.net,ivan.feysa@uzhnu.edu.ua, ivanushka@ukr.net

\author{
Слабкий Г.А., Миронюк И.С., Брич В.В., \\ Билак-Лукьянчук В.И., Маркович В.П., Потокий Н.И., \\ Яцина А.Т., Фейса И.И., Гуцол И.Я. \\ Образовательно-научная программа подготовки \\ магистров общественного здоровья Ужгородского \\ национального университета глазами стейкхолдеров \\ ГВУЗ «Ужгородский национальный университет», \\ г. Ужгород, Украина
}

Slabkiy G.O., Mironyuk I.S., Brych V.V., Bilak-Lukianchuk V.J., Markovych V.P., Potokiy N.J., Yatsyna A.T., Feisa I.I., Hutsol I.Ya.

Educational-and-scientific program of training masters of public health in Uzhhorod national university by the eyes of the stakeholders

Uzhhorod National University, Uzhhorod, Ukraine

\section{Встуі}

В 2016 році в Україні започатковано систему громадського здоров'я [1], а в 2018 році в Україні затверджено нову спеціальність - громадське здоров'я та затверджено національний стандарт вищої освіти 3 підготовки магістрів громадського здоров'я [2]. Перший набір на навчання студентів за магістерськими освітніми програмами спеціальності громадське здоров'я здійснено в 2019 році. Це вказує на те, що в Україні відсутній досвід розробки освітніх програм підготовки магістрів громадського здоров'я, що потребує постійної роботи з їх удосконалення. Головну роль в процесі оптимізації освітніх програм підготовки магістрів громадського здоров'я відіграють стейкхолдери. Їх участь у досліджені була застосована відповідно до «Положення про моніторинг якості освітнього процесу в ДВНЗ «Ужгородський національний університет» [3]. Правовою основою здійснення моніторингових досліджень є Закон України «Про вищу освіту» [4].

Мета роботи: провести оцінку освітньо-наукової програми підготовки магістрів громадського здоров'я Ужгородського національного університету стейкхолдерами з метою їі удосконалення.

\section{Матеріали та методи}

Стейкхолдерами для дослідження були визначені представники наступних цільових груп: академічна спільнота, майбутні роботодавці, студенти денної та заочної форми навчання за даною спеціальністю університету.

Для проведення анонімного опитування студентів і роботодавців були розроблені спеціальні анкети які розміщені на сайті Інфоцентру факультету і вказані стейкхолдери були проінформованими про режим доступу до анкет. Крім того потенційним роботодавцям були розіслані освітньо-наукова програма і анкети з проханням їх заповнити i направити на адресу кафедри. Участь студентів в заповнені анкет була анонімною.

Представникам академічної спільноти були професорсько-викладацький склад закладів вищої освіти в яких ведеться підготовка за спеціальністю «Громадське здоров'я» та науковці, які переймаються даною проблемою. Форма заключення представників академічної спільноти була довільною.

Всього в досліджені взяла участь наступна кількість стейхолдерів: представники академічної спільноти - 9, майбутні роботодавці - 11, студенти - 15 .

Викладачі кафедри прийняли участь в обговорені результатів опитування стейкхолдерів та висловлювали свої пропозиції.

Дослідження проводилося в період травня-червня 2020 року, що визначало період закінчення першого навчального року. Враховуючи дію карантину спілкування 3 респондентами проводилося в електронному режимі.

\section{Результати дослідження та їх обговорення}

Освітньо-наукова програма «Громадське здоров'я» другого (магістерського) рівня вищої освіти за спеціальністю 229 - Громадське здоров'я галузі знань 22 «Охорона здоров'я» Ужгородського національного університету затверджена рішенням Вченої ради університету 21.03.2019 року, протокол №4 i використовувалася протягом 2019-2020 навчального року 
під час першого набору магістрів за вказаною спеціальністю. Вченою радою затверджено перелік компонент освітньо-наукової програми та їх логічну послідовність.
В табл. 1 наведено перелік компонент програми та обсяг кожної компоненти в кредитах та форми підсумкового контролю.

\section{Таблиця 1. Компоненти освітньо-наукової програми}

\begin{tabular}{|c|c|c|c|}
\hline $\begin{array}{l}\text { Код } \\
\text { н/д }\end{array}$ & $\begin{array}{c}\text { Компоненти освітньої програми (навчальні } \\
\text { дисципліни, курсові проекти (роботи), практики, } \\
\text { кваліфікаційна робота) } \\
\end{array}$ & $\begin{array}{c}\text { Кількість } \\
\text { кредитів }\end{array}$ & $\begin{array}{c}\text { Форма } \\
\text { підсумкового } \\
\text { контроло } \\
\end{array}$ \\
\hline 1 & 2 & 3 & 4 \\
\hline \multicolumn{4}{|c|}{ Обов'язкові компоненти ОП } \\
\hline OK 1. & Вступ до спеціальності "Громадське здоров'я" & 4,5 & Iсnит \\
\hline OK 2. & Біостатистика & 4 & Залік \\
\hline OK 3. & Ділова англійська мова & 3 & Залік \\
\hline OK 4. & Організація охорони здоров'я в Україні & 4 & Icnut \\
\hline OK 5. & Профілактика в системі громадського здоров'я & 4,5 & Залік \\
\hline OK 6. & Основи епідеміологіï & 3 & за.лік \\
\hline OK 7. & Елідеміологія неінфекційних хвороб & 3,5 & Залік \\
\hline OK 8. & Епідеміологія інфекційних хвороб & 3 & Залік \\
\hline OK 9. & Інформатизація та комунікації в охороні здоров'я & 4 & IcnuT \\
\hline OK 10 . & Організація та презентація наукових досліджень & 4 & Iсnит \\
\hline OK 11. & Наукові комунікації у галузі громадського здоров'я & 4 & Iсnит \\
\hline OK 12. & Політика, етика, лідерство в громадському здоров'ї & 3 & Залік \\
\hline OK 13. & Програмний менеджмент в громадському здоров’ї & 4 & Icnut \\
\hline OK 14. & Управління якістю життя & 4 & Iсnит \\
\hline OK 15. & Моніторинг та оцінка в системі громадського здоров'я & 4 & IсnHT \\
\hline OK 16. & Науково-дослідна практика & 6 & Диф. залік \\
\hline OK 17. & Виконання кваліфікаційної роботи & 21 & IcnuT \\
\hline OK 18. & Атестація & 3 & Iспнт \\
\hline \multicolumn{2}{|c|}{ Загальний обеяг обов'язкових компонент } & \multicolumn{2}{|c|}{ 86,5 кредитів } \\
\hline \multicolumn{4}{|c|}{ Вибіркові көмпоненти ОП } \\
\hline \multicolumn{4}{|c|}{ Виб̆іркөвній блок 1 } \\
\hline BБ 1.1 . & Екологія людини/Глобальне здоров’я & 3 & Залік \\
\hline BБ 1.2 . & Гігієна праці/Професійна захворюваність & 3 & Залік \\
\hline \multicolumn{4}{|c|}{ Вибірковиій блок 2 } \\
\hline ВБ 2.1. & $\begin{array}{l}\text { Формування програм зменшення впливу факторів } \\
\text { ризику НІ3 на здоров'я населення/ Формування програм } \\
\text { збереження здоров'я населення на рівні громади }\end{array}$ & 4 & Залік \\
\hline ВБ 2.2 . & 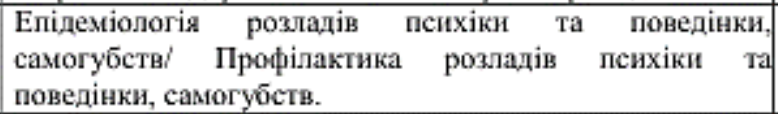 & 4,5 & Icnut \\
\hline ВБ 2.3 . & $\begin{array}{l}\text { Харчування як складова громадського здоров'я } \\
\text { Моніторинг та оцінка впливу харчування на здоров'я } \\
\text { населення }\end{array}$ & 3 & Залік \\
\hline ВБ 2.4 . & $\begin{array}{l}\text { Відновлення здоров'я та працездатності в системі } \\
\text { громадського здоров'я / Охорона репродуктивного } \\
\text { здоров'я населення }\end{array}$ & 4 & Iсnит \\
\hline ВБ 2.5 . & $\begin{array}{l}\text { Моніторинг та реагування на надзвичайні ситуації в } \\
\text { сфері охорони здоров'я / Біобезпека територій }\end{array}$ & 4 & Iсnит \\
\hline BБ 2.6. & $\begin{array}{l}\text { Економіка громадського } \quad \text { здоров'я/ Фінансовий } \\
\text { менеджмент програм громадського здоров'я }\end{array}$ & 3,5 & Залік \\
\hline ВБ 2.7 . & $\begin{array}{l}\text { Правове забезпечення громадського здоров'я/ Права } \\
\text { особи в охороні здоров'я }\end{array}$ & 4,5 & Залік \\
\hline \multicolumn{2}{|c|}{ Загальний обеяг вибіркових компонент } & \multicolumn{2}{|c|}{ 33,5 кредитів } \\
\hline \multicolumn{2}{|c|}{ ЗАГАЛЬНИЙ ОБСЯГ ОСВІТНЬОЙ ПРОГРАМИ } & \multicolumn{2}{|c|}{120 кредитів } \\
\hline
\end{tabular}

Освітня програма включає 16 обов'язкових навчальних дисциплін, науково-дослідну практику, виконання кваліфікаційної роботи та атестацію, що становить 86,5 кредитів. Назване складає обов'язковий блок освітньої програми.
Вибірковий блок освітньо-наукової програми включає 9 навчальних дисциплін на вибір, які складають 33,5 кредитів. Вибіркові дисципліни викладаються на першому та другому курсах навчання, починаючи 3 першого семестру. 
Освітньо-наукова програма складалася таким чином, щоб забезпечити освоєння студентами необхідних компетенцій та включає питання, які відповідають всім основним оперативним функціям системи громадського здоров'я.

Освітня програма включає також програмні результати навчання. Вони представлені в табл. 2.

Досягнення студентами програмних результатів навчання мають забезпечити їх ефективну практичну діяльність по закінченню навчання в університеті.

Стейкхолдерами аналізувалися компоненти освітньо-наукової програми та програмні результати навчання.

Стейкхолдери, які прийняли участь у дослідженні зробили наступні зауваження та пропозиції до змісту компонент освітньої програми та розподілу навчальних дисциплін за вибором за семестрами навчання.

Представники академічної

спільноти запропонували об'єднати в одну навчальну дисципліну наступні навчальні дисципліни «Організація та презентація наукових досліджень» і «Наукові комунікації у галузі громадського здоров'я» 3 загальною кількістю кредитів 6,5 3 передачею 1,5 кредитів на предмет
«Епідеміологія інфекційних захворювань». В першому семестрі не викладати предмети за вибором.

Майбутні роботодавці запропонували більше уваги приділити прикладній медичній статистиці та аналізу отриманих даних відповідно до місцевих та регіональних умов, навчання студентів методології епідеміологічних досліджень та моніторингу і оцінці серед трудових мігрантів та їх найближчого оточення, проведення серед них профілактичної роботи.

Студенти: збільшити кількість навчальних годин 3 епідеміології та вивчати методику проведення епідеміологічного дослідження при інфекційних захворюваннях.

Викладачі: перейти на циклову форму проведення занять и практикувати проведення занять на можливих базах майбутньої роботи студентів.

Стейкхолдери запропонували доповнити програмні результати навчання наступними пунктами:

1. Розробляти заходи забезпечення біобезпеки на рівні громад.

2. Забезпечувати комплексні профілактичні заходи в середовищі трудових мігрантів та їх близького оточення.

3. Охоплювати заходами 3 промоції здоров'я жителів віддалених гірських населених пунктів.

\section{Таблиця 2. Програмні результати навчання}

1. Демонструвати здатність до абстрактного мпслення, аналізу та синтезу.

2. Розуміти, як організовувати дослідження на відповідних рівнях та обирати для цього відповідні дизайни досліджень.

3. Застосовувати іноземну (англійську) мову для професійного спілкування.

4. Критично інтерпретувати факти та знаходити обгрунтовані рішення

5. Знати принципи улравління проектами та мати навички розробки проектів.

6. Враховувати соціальну відповідальність при виборі альтернатив.

7. Оцінювати, інтерпретувати та порівнювати основні епідеміологічні та демографічні показники, значення детермінант здоров'я у розрізі різних груп населення в Україні, Европейському регіоні та світі.

8. Визначати пріоритети і проводити оцінку потреб громадського здоров'я в конкретній ситуаціi.

9. Розробляти варіанти стратегій, політик та визначати окремі інтервенції, спрямовані на збереження та зміцнення здоров'я населення та оцінювати іх ефективність.

10. Проектувати заходи з нагляду за станом здоров'я населення.

11. Аналізувати вплив різних детермінант (соціальних, економічних, індивідуальних, навколишнього середовища) на здоров'я населення та організовувати відповіді заходи 3 ї попередження.

12. Оцінювати ризики та організовувати дії у відповідь на надзвичайні снтуації в сфері громадського здоров'я.

13. Розробляти заходи з профілактики (первинної, вторинно̄̄ та третинно̆) захворювань та розуміти, як іх реалізовувати на практиці.

14. Розробляти та організовувати заходи з промоції здоров'я.

15. Аналізувати економічну ефективність стратегій, політик та інтервенцій в сфері громадського здоров'я та пропонувати заходи щодо підвнщення такої ефективності.

16. Викладати основи громадського здоров'я.

17. Розробляти проекти надання лослуг громадського здоров'я, контролю якості іх надання, знати основи управління.

18. Планувати та організовувати заходи 3 адвокації, комунікації та соціальної мобілізації у сфері громадського здоров'я.

19. Демонструвати лідерство на рівні спільнот щодо громадського здоров'я

20. Слідувати етичним принципам та нормам права при плануванні досліджень, зборі інформації та ї̈ використанні. 
Перспективи подальших досліджень пов'язані 3 проведенням самооцінки студентами-магістрами готовності до використання набутих компетенцій в майбутній практичній роботі.

\section{Висновки}

Запропоновані стейкхолдерами пропозиції щодо удосконалення освітньо-наукової програми мають бути обговорені на засіданні кафедри і враховані при розробці нового варіанту програми.

\section{Лiтература}

1. Розпорядження КМУ від 30 листопада 2016 р. № 1002-р «Про схвалення Концепції розвитку системи громадського здоров'я» [Електронний ресурс]. Режим доступу: https://zakon.rada.gov.ua/laws/show/1002-2016$\%$ D1\%80\#n8. - Назва з екрану.

2. Наказ МОН України від 12.12.2018 № 1383 «Про затвердження стандарту вищої освіти за спеціальністю 229 «Громадське здоров’я» для другого (магістерського) рівня вищої освіти» [Електронний ресурс]. Режим доступу: https://mon.gov.ua/storage/app/media/vishcha-osvita/zatverdzeni\%20standarty/12/21/229-gromadske-zdorovya-magistr.pdf. Назва з екрану.

3. Наказ ректора ДВНЗ «УжНУ» №750/01-17 від 28.05.2015 р. «Про затвердження «Положення про моніторинг якості освітнього процесу в ДВНЗ «Ужгородський національний університет» [Електронний ресурс]. Режим доступу: https://www.uzhnu.edu.ua/uk/infocentre/get/6141. - Назва з екрану.

4. Закон України «Про вищу освіту» від 1 липня 2014 року № 1556-VII [Електронний ресурс]. Режим доступу: https://taxlink.ua/ua/normative_acts/zakon-ukraini-pro-vishchu-osvitu. - Назва з екрану.

\section{References}

1. Rozporyadzhennya KMU vid 30 lystopada 2016 r. № 1002-r «Pro skhvalennya Kontseptsiyi rozvytku systemy hromads'koho zdorov"ya» [Elektronnyy resurs]. Rezhym dostupu: https://zakon.rada.gov.ua/laws/show/1002-2016\%D1\%80\#n8. - Nazva z ekranu.

2. Nakaz MON Ukrayiny vid 12.12.2018 № 1383 «Pro zatverdzhennya standartu vyshchoyi osvity za spetsial'nistyu 229 «Hromads'ke zdorov"ya» dlya druhoho (mahisters'koho) rivnya vyshchoyi osvity» [Elektronnyy resurs]. Rezhym dostupu: https://mon.gov.ua/storage/app/media/vishcha-osvita/zatverdzeni\%20standarty/12/21/229-gromadske-zdorovya-magistr.pdf. Nazva z ekranu.

3. Nakaz rektora DVNZ «UzhNU» №750/01-17 vid 28.05.2015 r. «Pro zatverdzhennya «Polozhennya pro monitorynh yakosti osvitn'oho protsesu v DVNZ «Uzhhorods'kyy natsional'nyy universytet» [Elektronnyy resurs]. Rezhym dostupu: https://www.uzhnu.edu.ua/uk/infocentre/get/6141. - Nazva z ekranu.

4. Zakon Ukrayiny «Pro vyshchu osvitu» vid 1 lypnya 2014 roku № 1556-VII [Elektronnyy resurs]. Rezhym dostupu: https://taxlink.ua/ua/normative_acts/zakon-ukraini-pro-vishchu-osvitu. - Nazva z ekranu.

Дата надходження рукопису до редакції: 07.05.2020 p.

Мета роботи: провести оцінку освітньо-наукової програми підготовки магістрів громадського здоров’я Ужгородського національного університету стейкхолдерами з метою їі удосконалення.

Матеріали та методи. Всього в досліджені взяла участь наступна кількість стейкхолдерів: представники академічної спільноти - 9, майбутні роботодавці - 11, студенти - 15. Викладачі кафедри прийняли участь в обговорені результатів опитування стейкхолдерів та висловлювали свої пропозиції. Дослідження проводилося в період травнячервня 2020 року, що визначало період закінчення першого навчального року.

Результати. Представники академічної спільноти запропонували об'єднати в одну навчальну дисципліну наступні навчальні дисципліни «Організація та презентація наукових досліджень» і «Наукові комунікації у галузі громадського здоров'я» 3 загальною кількістю кредитів 6,5 3 передачею 1,5 кредитів на предмет «Епідеміологія інфекційних захворювань». В першому семестрі не викладати предмети за вибором.

Майбутні роботодавці запропонували більше уваги приділити прикладній медичній статистиці та аналізу отриманих даних відповідно до місцевих та регіональних умов, навчання студентів методології епідеміологічних досліджень та моніторингу і оцінці серед трудових мігрантів та їх найближчого оточення, проведення серед них профілактичної роботи.

Студенти: збільшити кількість навчальних годин 3 епідеміології та вивчати методику проведення епідеміологічного дослідження при інфекційних захворюваннях.

Викладачі: перейти на циклову форму проведення занять и практикувати проведення занять на можливих базах майбутньої роботи студентів. 
Висновки. Запропоновані стейкхолдерами пропозиції щодо удосконалення освітньо-наукової програми мають бути обговорені на засіданні кафедри і враховані при розробці нового варіанту програми.

Ключові слова: громадське здоров’я, магістри, підготовка, освітньо-наукова програма, стейкхолдери, оцінка.

Цель работы: провести оценку образовательно-научной программы подготовки магистров общественного здоровья Ужгородского национального университета стейкхолдерами с целью её усовершенствования.

Материалы и методы. Всего в исследовании приняло участие такое количество стейкхолдеров: представители академического сообщества - 9, будущие работодатели - 11, студенты - 15. Преподаватели кафедры принимали участие в обсуждении результатов опроса стейкхолдеров и высказывали свои предложения. Исследование проводилось в период мая-июня 2020 года, что определило окончание первого учебного года.

Результаты. Представители академического сообщества предложили объединить в одну учебную дисциплину следующие учебные дисциплины: «Организация и презентация научных исследований» и «Научные коммуникации в отрасли общественного здоровья» с общим количеством кредитов 6,5 с передачей 1,5 кредитов на предмет «Эпидемиология инфекционных заболеваний». В первом семестре не преподавать предметы по выбору.

Будущие работодатели предложили больше внимания уделить прикладной медицинской статистике и анализу полученных данных относительно местных и региональных условий, обучению студентов методологии эпидемиологических исследований, мониторинга и оценки среди трудовых мигрантов и их ближайшего окружения, проведения среди них профилактической работы.

Студенты: увеличить количество учебных часов по эпидемиологии и изучать методику проведения эпидемиологического исследования при инфекционных заболеваниях.

Преподаватели: перейти на цикловую форму проведения занятий и практиковать проведение занятий на возможных базах будущей работы студентов.

Выводы. Предложенные стейкхолдерами пропозиции об усовершенствовании образовательно-научной программы должны быть обсуждены на заседании кафедры и учтены при разработке нового варианта программы.

Ключевые слова: общественное здоровье, магистры, подготовка, образовательно-научная программа, стейкхолдеры, оценка.

Goal of research: to perform the assessment of the educational-and-scientific program of training Masters of Public Health in Uzhgorod National University by stakeholders in order to improve it.

Materials and methods. In total, the following number of stakeholders took part in the research: the representatives of the academic community -9 , future employers -11 , students -15 . The department lecturers took part in the discussion of the results of the stakeholders' survey and expressed their proposals. The study was conducted in the period of May-June 2020, which determined the end of the first academic year.

Results. The representatives of the academic community offered to unite in one educational discipline the following subjects "Organization and presentation of scientific researches" and "Scientific communication in the field of public health" with the total number of credits 6.5 with the transfer of 1.5 credits for "Epidemiology of Infectious Diseases" and also not to teach the subjects of choice in the first semester.

Future employers offered to pay more attention for the applied medical statistics and analysis of the obtained data in accordance with local and regional conditions, teaching students of the methodology of epidemiological studies and monitoring and evaluation among migrant workers and their immediate environment, carrying out preventive work among them.

Students: to increase the number of study hours for epidemiology and to study the methodology of epidemiological research in infectious diseases.

Teachers: to change to the cycle form of conducting classes and to practice conducting classes on possible bases for future work of students.

Conclusions. Stakeholders' suggestions for improvement of the educational-and-scientific program should be discussed at the Department meeting and are to be taken into account in the development of a new version of the program.

Key words: public health, masters, training, educational-and-scientific program, stakeholders, assessment.

Конфлікт інтересів: відсутній.

Conflicts of interest: authors have no conflicts of interest to declare. 


\section{Відомості про авторів}

Слабкий Геннадій Олексійович - доктор медичних наук, професор, завідувач кафедри наук про здоров'я ДВНЗ «Ужгородський національний університет»; 88000 пл. Народна, 3, м. Ужгород, Україна. g.slabkiy@ukr.net.

Миронюк Іван Святославович - доктор медичних наук, професор, декан факультету здоров'я та фізичного виховання ДВНЗ «Ужгородський національний університет»; 88000 пл. Народна, 3, м. Ужгород, Україна. ivan.mironyuk@gmail.com.

Брич Валерія Володимирівна - кандидат медичних наук, доцент кафедри наук про здоров’я ДВНЗ «Ужгородський національний університет»; 88000 пл. Народна, 3, м. Ужгород, Україна.

leravvv79@gmail.com.

Білак-Лук'янчук Вікторія Йосипівна - кандидат медичних наук, доцент кафедри наук про здоров'я ДВНЗ «Ужгородський національний університет»; 88000 пл. Народна, 3, м. Ужгород, Україна.

bilak.vika@gmail.com.

Маркович Володимир Петрович - кандидат медичних наук, доцент кафедри наук про здоров’я ДВНЗ «Ужгородський національний університет»; 88000 пл. Народна, 3, м. Ужгород, Україна.

v.markovych@i.ua.

Потокій Наталія Йосипівна - кандидат медичних наук, асистент кафедри наук про здоров’я ДВНЗ «Ужгородський національний університет»; 88000 пл. Народна, 3, м. Ужгород, Україна.

rigerbird@gmail.com.

Яцина Андреа Тіборівна - кандидат медичних наук, асистент кафедри наук про здоров’я ДВНЗ «Ужгородський національний університет»; 88000 пл. Народна, 3, м. Ужгород, Україна.

andreayatsyna@ukr.net.

Фейса Іван Іванович - старший викладач кафедри наук про здоров'я факультету здоров'я та фізичного виховання ДВНЗ «Ужгородський національний університет»; 88000 пл. Народна, 3, м. Ужгород, Україна.

ivan.feysa@uzhnu.edu.ua.

Гуцол Іванна Ярославівна - викладач кафедри наук про здоров'я факультету здоров'я та фізичного виховання ДВНЗ «Ужгородський національний університет»; 88000 пл. Народна, 3, м. Ужгород, Україна.

ivanushka@ukr.net. 